\title{
E.M.W. Skinner
}

Geology Department, De Beers Consolidated Mines Ltd., Kimberley.

\section{INTRODUCTION}

Southern African kimberlites can be subdivided into two distinct groups (termed Group 1 and Group 2, e.g. Smith, 1983) on the basis of differences in distribution, petrography, content of mantle-derived xenocrysts and xenoliths, isotopic character, age and whole-rock geochemistry. The contrasting petrology of the two groups has important implications for models of kimberlite genesis.

\section{CONTRASTING PETROLOGY}

To date 162 occurrences out of a total of approximately 840 southern African kimberlites, have been identified as Group 2 varieties. These are distributed within a belt ( $\pm 400 \times 1250 \mathrm{~km}$ ) extending from Eendekuil (near Sutherland, western Cape) in the south-west to Dokolwayo (Swaziland) in the north-east. Group l kimberlites are more widely distributed. Group 2 kimberlites have been identified only in southern Africa.

\section{Broad Petrographic Distinctions}

Group 1 kimberlites are characterised by several of the following major (volumetrically abundant) matrix minerals; monticellite, calcite, serpentine and phlogopite. Groundmass spinels and perovskite are typically abundant and relatively coarse-grained. Groundmass ilmenite may be present. Olivine phenocrysts in Group l's are generally less than $1 \mathrm{~mm}$ in size and commonly contain small inclusions of rutile. olivine xenocryst to phenocryst ratios, in terms of volume, commonly approximate $1: 1$.

Group 2 kimberlites are nearly always dominated by phenocrysts or groundmass phlogopite with or without diopside. Groundmass spinels and perovskite, if present, are rare and small. Groundmass ilmenite does not occur. Olivine phenocrysts in Group 2 's vary considerably in size and abundance relative to xenocrysts. Rutile inclusions in olivine phenocrysts have not been found.

Both xenocryst and phenocryst olivines in several Group 2 kimberlites exhibit pronounced overgrowths. Core compositions of individual xenocrysts and phenocrysts are uniform with respect to both major and minor elements. However populations of both xciocrysts and phenocrysts may exhibit variable compositions (e.g. Fog3 to Fo87 for xenocryst cores and Fog5 to Fo8g for phenocryst cores). In contrast overgrowth compositions are always similar irrespective of whether the core is a xenocryst or phenocryst. Overgrowth compositions are uniform with respect to major elements (e.g. Fogo) but $\mathrm{Ni}, \mathrm{Mn}$ and $\mathrm{Ca}$ vary. Nickel typically increases from about 0,4 wt.\% (core content) to about $0,55 \mathrm{wt} . \%$ at the core - overgrowth boundary. It then decreases rapidly towards the overgrowth $\operatorname{rim}(e . g .0,2$ wt. $\%$ ).

\section{Mantle-derived Constituents}

Most Group 1 kimberlites carry a full suite (e.g. olivine, ilmenite, garnet, chromite, cpx., opx. and zircon) of mantle-derived xenocrysts although some are devoid of ilmenite. All 'on-craton' Group 2 kimberlites are essentially devoid of ilmenite and zircon xenocrysts. Garnet, chromite and olivine xenocryst populations in 'on-craton' Group 2's appear to be compositionally more homogeneous than these populations in Group 1 varieties.

Olivine xenocrysts are by far the most abundant mantle-derived mineral in both groups of kimberlite. Apart from xenocrystal phlogopite and ilmenite which may reach up to about 4 vol.\%, other xenocrysts rarely exceed 1 vol.\% Not only is orthopyroxene very much less abundant than olivine but it is also less abundant than garnet and clinopyroxene. This is surprising in view of the likelihood that the source rocks of kimberlite contain significant proportions of orthopyroxene. 
Similar variations in the proportions of peridotite and eclogite xenolith populations are evident for both groups of kimberlite. However, mantle metasomatised peridotites and 'marid'-type xenoliths are rare in Group 2 occurrences.

Smith (1983) maintains that deformed, "hot" peridotites (containing high Ti garnets) are found only in Group 1 kimberlites. He uses this to support his hypothesis that Group l's are asthenosphere- derived. This argument is, to some extent, supported by the general scarcity of titanium-rich garnets in Group 2 kimberlites (the Dokolwayo kimberlite being a notable exception). Xenolith proportions and heavy mineral suites are commonly poorly correlated in any particular kimberlite. For example, at Roberts Victor, garnets picked out of heavy mineral concentrate are dominated by peridotitic types whereas the xenolith population is mainly eclogitic. Some xenoliths and xenocrysts are isotopically out of equilibrium with the host kimberlite. This is true of both groups of kimberlite. Such xenoliths and xenocrysts have little bearing on the nature of the source rocks. Most xenoliths and many xenocrysts may in fact merely represent higher level mantle constituents picked up by an already well-developed (isotopically and geochemically distinct) kimberlite magma.

\section{Isotopes and Ages}

Smith (1983) showed that most Group 1 kimberlites are isotopically slightly depleted relative to Bulk Earth with respect to $\mathrm{Sr}$ and $\mathrm{Nd}$. $\mathrm{Pb}$ values are relatively radiogenic and variable. In contrast Group 2 kimberlites are isotopically enriched relative to Bulk Earth with respect to $\mathrm{Sr}$ and $\mathrm{Nd}$. $\mathrm{Pb}$ isotopes are relatively unradiogenic. Group $1^{\prime}$ s are considered by Smith (1983) to be derived from asthenospheric-like sources whereas Group 2's are thought to be derived from lithospheric sources with an isotopic character indicative of ancient (metasomatic) enrichment.

Group 1 kimberlites range in age from about 1600 to about 50 million years. In southern Africa most of these fall within the time span from \pm 250 to $50 \mathrm{~m}$.y. A vague periodicity of volcanism is evident. In contrast Group 2 kimberlites range in age from about 110 to 200 million years (a time span of only $90 \mathrm{m.y.}$ ) and ages increase progressively from Eendekuil to Dokolwayo. It is notable that the $200 \mathrm{~m} . \mathrm{y}$. age of Dokolwayo broadly correlates with the opening of the Indian ocean whereas the younger Eendekuil age broadly correlates with the opening of the Atlantic. Group 1 kimberlites do not exhibit well-defined age patterns.

Where Cretaceous kimberlites occur in the same area Group 2's are always older than Group $1^{\prime} \mathrm{s}$ and age differences range from about $5 \mathrm{~m} . \mathrm{y}$. (e.g. in the Harts River Valley area) to about $55 \mathrm{~m} . \mathrm{y}$. (e.g. in the Swartruggens area).

\section{Whole-rock Geochemistry}

Group 2 kimberlites are characterised by higher levels of $\mathrm{SiO}_{2}, \mathrm{~K}_{2} \mathrm{O}, \mathrm{Rb}, \mathrm{Ba}$ and LREE but lower $\mathrm{CO}_{2}, \mathrm{TiO}_{2}$ and $\mathrm{Nb}$ compared to Group $1^{\prime} \mathrm{s}$ (Smith et al, in press). Correlations between $\mathrm{SiO}_{2}$ and $\mathrm{CO}_{2}$ may reflect different source rock conditions as well as differences in the degree of evolution. Considering the former, if the source peridotite is relatively enriched in $\mathrm{CO}_{2}$, experimental evidence indicates that the orthopyroxene field is expanded and the resultant melt is relatively undersaturated with respect to silica.

In spite of suggestions by Smith (1983) broad similarities of major element composition and trace element abundance patterns suggest that both groups of kimberlite may perhaps have been generated within the lithosphere with Group l's being derived from parts of the lithosphere that have not undergone isotopic and other enrichment processes.

Relative deficiencies in $\mathrm{TiO}_{2}$ and $\mathrm{Nb}$ in Group 2 's may relate to the evidence provided by xenocryst and xenolith populations which indicates that Group 2 's are derived from source rocks that are essentially devoid of ilmenite, rutile and zircon. Deficiencies in $\mathrm{TiO}_{2}$ may, however, also be consistent with differences in the degree of "evolution" with more highly "evolved" rocks containing higher $\mathrm{TiO}_{2}$. 
The contrasting petrological nature of Group 1 and Group 2 kimberlites allows the development of a new model for kimberlite genesis and emplacement. The main aspects of this model, which requires some fundamental assumptions, are presented below:

(1) It is assumed that kimberlite volcanism occurs as a result of the introduction of heat or volatile elements from below.

(2) Kimberlite magmas are initially generated by small degrees of partial melting from isotopically and geochemically distinct lithospheric source rocks. However, melting of the Group 2 source rocks, will be accelerated by the presence of higher proportions of $\mathrm{K}_{2} \mathrm{O}, \mathrm{Rb}, \mathrm{Ba}$, LREE and $\mathrm{H}_{2} \mathrm{O}$. Smaller amounts of $\mathrm{CO}_{2}$ relative to $\mathrm{H}_{2} \mathrm{O}$ will favour an increased contribution from the orthopyroxene component in peridotite resulting in relatively higher $\mathrm{SiO}_{2}$ in Group 2 magmas.

(3) Compositional restrictions with respect to mantle-derived xenocrysts and the absence of Ti-rich xenoliths and xenocrysts indicates that Group 2 kimberlites are derived from a smaller segment of the upper mantle compared with Group 1 kimberlites.

(4) The fact that Group 2 kimberlites predate Group 1 kimberlites in the same area indicates that, if the genesis of both magmas is initiated by the same or similar volcanic processes, then Group 2 magmas are generated faster and are emplaced sooner than Group 1 kimberlites.

(5) The almost linear age progression of Group 2's and the apparent association between age and break up of Gondwanaland may indicate that hot-spot activity is more important in respect of the generation of Group 2 magmas. The transfer of heat and associated volatile elements from a stationary hot-spot into the upper moving plate is likely to be more effective where the plate has been preconditioned, by the earlier addition of other incompatible elements.

(6) The compositional variations exhibited by olivine xenocrysts and phenocrysts may provide valuable clues to processes of genesis and emplacement. Following the model first projected by Clement (1984) it is proposed that early (larger and generally more refractory) olivine phenocrysts crystallise from small pockets of magma. These magma pockets move upwards and subsequently coalesce to form a larger magma diapir which continues to ascend. Olivine xenocrysts (derived from the break-up of peridotitic wall rocks of differing composition) are incorporated into this magma. Both xenocrysts and early phenocrysts exhibiting partial resorption are subsequently armoured by overgrowths of olivine. These, together with smaller phenocrysts, crystallise at constant $\mathrm{Mg} /(\mathrm{Mg}+\mathrm{Fe})$ but changing $\mathrm{Ni}$ content. Uniform overgrowth compositions suggest that equilibrium conditions are attained within the magma (with respect to major elements) but $\mathrm{Ni}$ variation probably reflects the greater sensitivity of this element to changing pressure, temperature, wall-rock composition and oxygen fugacity during upward migration.

(7) Upward movement of the enlarged diapir may be accelerated as a result of the relative increase in volatiles in the residual melt caused by crystallisation of relatively large amounts of late-stage olivine and the incorporation of xenocrysts.

(8) Decelerated ascent close to surface possibly is caused by loss of energy through degassing as evidenced by large proportions of secondary fluid inclusions in both xenocryst and phenocryst olivines.

\section{REFERENCES}

Clement C.R. 1982. A comparative geological study of some major kimberlite pipes in the northern Cape and Orange Free State. PhD thesis (unpubl.) Univ. Cape Town, 432pp.

Smith C.B. 1985. Rubiduim-strontium, uranium-lead, and samarium-neodymium isotopic studies of kimberlites and related mantle-derived xenoliths. $\mathrm{Ph} . \mathrm{D}$ thesis (unpubl.), Univ. Witwatersrand, 436pp.

Smith C.B., Gurney J.J., Skinner E.M.W., Clement C.R., \& Ebrahim N. 1985. Geochemical character of southern African kimberlites. A new approach based on isotopic constraints. Trans. Geol. Soc. S. Afr., 88(2) in press. 